\title{
Gambaran Terapi dan Luaran Infeksi Saluran Kemih oleh Bakteri Penghasil Extended Spectrum Beta Lactamase pada Anak di RSUD Dr. Soetomo Surabaya
}

\author{
Ahmad Siddiq Muhajir, ${ }^{*}$ Priyo Budi Purwono,* Samsriyaningsih Handayani*** \\ *Mahasiswa S1 Fakultas Kedokteran, ${ }^{* *}$ Departemen Mikrobiologi Klinik RSUD Dr. Soetomo Surabaya, ${ }^{* * *}$ Departemen Ilmu \\ Kesehatan Masyarakat Fakultas Kedokteran Universitas Airlangga
}

\begin{abstract}
Latar belakang. Kasus infeksi saluran kemih oleh bakteri penghasil extended spectrum beta-lactamase (ESBL) dilaporkan sudah banyak terjadi di dunia. Informasi terkait ESBL di Indonesia sangat sedikit, terutama pada pasien anak.

Tujuan. Mengkaji gambaran terapi serta luaran pasien infeksi ESBL di RSUD Dr. Soetomo Surabaya periode Januari-Juni 2014.

Metode. Penelitian observasional dengan studi deskriptif, digunakan data rekam medis pasien anak RSUD Dr. Soetomo Surabaya periode Januari-Juni 2014. Variabel penelitian meliputi bakteri, uji sensitivitas, terapi serta status luaran pasien.

Hasil. Pasien anak berjumlah 56, terbanyak penyebab ISK Klebsiella pneumoniae (60,7\%). Uji sensitivitas tertinggi meropenem (90,5\%). Pilihan terapi definitif meropenem (25\%), status luaran membaik 78,57\%.

Kesimpulan. Meropenem merupakan pilihan terapi infeksi ESBL pada pasien dengan keadaan klinis membaik. Kontrol penggunaan antibiotik secara rasional dibutuhkan untuk pencegahan infeksi ESBL Sari Pediatri 2016;18(2):111-6
\end{abstract}

Kata kunci: extended spectrum beta-lactamase, ESBL pada anak, pola sensitivitas antibiotik, resistensi antibiotik, infeksi saluran kemih

\section{Therapy and Outcome of Pediatric Urinary Tract Infection Caused by Extended Spectrum Beta-Lactamase (ESBL) Producing Bacteria in Soetomo Hospital Surabaya}

\author{
Ahmad Siddiq Muhajir, ${ }^{*}$ Priyo Budi Purwono, ${ }^{* *}$ Samsriyaningsih Handayani ${ }^{* * *}$
}

Background. Urinary tract infection caused by extended-spectrum beta-lactamase (ESBL) producing Enterobacteriaceae have been frequently reported worldwide. We have no information on such problem in Surabaya, Indonesia.

Objective. This study was aimed to determine the therapy and outcome of ESBL producing Enterobacteriaceae in Dr. Soetomo Hospital Surabaya, Indonesia from January through-June 2014.

Method. This research was a descriptive study. Data were recorded and analyzed from medical record which included of ESBL bacterial distribution, antibiotic sensitivity pattern, history of therapy, also the outcomes during January-June 2014 period in Dr. Soetomo Hospital, Surabaya.

Result. There were 56 children with ESBL infection in Dr. Soetomo Hospital Surabaya during January-June 2014. The incidence was high in $1-5$ years age group Klebsiella pneumoniae was the most common $(60,7 \%)$ bacteria producing ESB, with highest sensitivity of $90.5 \%$ toward meropenem. The definitive choice of treatment meropenem $(25 \%)$ and the outcome status was that most patients $(78,57 \%)$ were clinically improved.

Conclusion. Meropenem was most chosen drug to treat the ESBL infection resulting in patient's clinical improvement. Program focusing on rational use of antibiotics, invasive treatments, and nursing care are important for prevention and control of ESBL infection. Sari Pediatri 2016;18(2):111-6

Keyword : extended spectrum beta-lactamase, ESBL in children, antibiotic sensitivity pattern, antimicrobial resistance, nosocomial infection

\footnotetext{
Alamat korespondensi: Dr. Ahmad Siddiq Muhajir. Fakultas Kedokteran Universitas Airlangga, Jl. Mayjend Prof. Dr. Moestopo 47 Surabaya. Email: siddiqmuhajir@rocketmail.com
} 
Ahmad Siddiq Muhajir dkk: Gambaran terapi dan luaran pasien ISK oleh bakteri penghasil ESBL

$\mathrm{P}$ enyebab terbanyak infeksi saluran kemih pada pasien anak adalah enterobacteriaceae, seperti Escherichia coli dan klebsiella pneumoniae. ${ }^{1}$ Pemberian terapi empiris infeksi saluran kemih menggunakan antibiotik spektrum luas, seperti penisilin dan sefalosporin secara tidak rasional menjadi salah satu pemicu resistensi. Tahun 1983 pertama kali ditemukan kasus extended spectrum beta-lactamases (ESBL) yang diproduksi Klebsiella pneumoniae. ${ }^{2}$ Ditemukan strain yang sama pada Escherichia coli di tahun $1987 .{ }^{3}$ Sampai saat ini, laporan terkait kasus resistensi bakteri penghasil ESBL terus mengalami peningkatan di dunia. ${ }^{4}$ Prevalensi kasus infeksi oleh bakteri penghasil ESBL mencapai $29 \%$ pada E.coli dan 36\% pada K.pneumoniae di Indonesia. Prevalensi ESBL berdasarkan konfirmasi gen SHV mencapai 42,67\%. ${ }^{5}$

Extended spectrum beta-lactamases adalah enzim yang diproduksi oleh bakteri Gram negatif. ${ }^{6}$ Bakteri jenis ini memiliki kemampuan untuk menghidrolisis cincin membran $\beta$-laktam, seperti antibiotik golongan penicillin, cephalosporin generasi satu, dua, dan tiga serta golongan aztreonam. Berasal dari $\beta$-laktamase yang termutasi dikode melalui plasmid sehingga menyebabkan peningkatan aktivitas enzimatik $\beta$-laktamase. Hal ini menyebabkan dinding sel bakteri resisten terhadap antibiotik. ${ }^{7}$ Karbapenem dianggap sebagai pilihan terapi pada ESBL karena mmemiliki sensitivitas tinggi dan rentan terhadap hirolisis cincin membrane $\beta$-laktam. ${ }^{6}$

Resistensi antimikroba menjadi masalah baru di masyaraat. Pemberian terapi menjadi terbatas, sulit, dan mahal. Praktik kesehatan yang berlebihan dalam penggunaan antimikroba tentu tidak memberikan manfaat dalam upaya pencegahan kasus resistensi. ${ }^{4}$ Tujuan penelitian ini adalah untuk mengkaji gambaran pemberian terapi antibiotik bakteri penghasil ESBL beserta hasil luaran pada anak yang menjalani rawat inap di RSUD Dr. Soetomo, Surabaya, periode Januari-Juni 2014. Penelitian ini diharapkan dapat memberi informasi mengenai kasus infeksi ESBL pada anak di rumah sakit serta dapat dijadikan acuan oleh penelitian lain yang terkait. Data spesifik terkait kasus resistensi bakteri penghasil ESBL di Indonesia sangat terbatas, terutama pasien anak. Kasus ESBL belum menjadi prioritas masalah utama kesehatan terutama pada bidang pediatri. Oleh karena itu, masih diperlukan data lebih lanjut.

\section{Metode}

Jenis penelitian deskriptif observasional yang bersifat retrospektif dengan data sekunder berupa dokumentasi rekam medik pasien. Sampel penelitian adalah sebagian anak pasien infeksi bakteri penghasil ESBL yang menjalani terapi rawat inap di RSUD Dr. Soetomo, Surabaya, periode Januari-Juni 2014 dengan teknik total sampling pada pasien yang memenuhi kriteria inklusi.

Kriteria sampel terdiri atas (1) anak dengan kriteria usia $<19$ tahun yang menjalani rawat inap, (2) positif infeksi saluran kemih oleh bakteri penghasil ESBL melalui double disk synergy test dengan uji konfirmasi phoenix system dari spesimen kateter urin oleh Laboratorium Mikrobiologi Klinik RSUD Dr. Soetomo Surabaya, (3) memilikki data uji sensitivitas bakteri penghasil ESBL terhadap antibiotik melalui uji diffusiin disk, (4) menjalani terapi antibiotik baik empiris maupun definitif, (5) memiliki data dokumentasi rekam medis lengkap sesuai variabel yang dibutuhkan peneliti.

Variabel yang diteliti berupa bakteri penghasil ESBL beserta uji sensitivitasnya terhadap antibiotik, terapi antibiotik definitif serta luaran pasien setelah dirawat. Data yang didapatkan diolah dengan statistik deskriptif dan disajikan dalam tabel.

\section{Hasil}

Jumlah pasien rawat inap anak yang terinfeksi saluran kemih oleh bakteri penghasil enzim ESBL dari spesimen urin di RSUD Dr. Soetomo Surabaya periode Januari-Juni 2014 berjumlah 56 pasien. Karakteristik sampel terdiri atas jenis kelamin laki-laki 35 (62,5\%) dan perempuan $21(37,5 \%)$ pasien. Data usia pasien berkisar antara 4 hari sampai 17 tahun, rerata 4,75 tahun ( \pm SD 4,55 tahun), median 3 tahun serta modus 1 tahun dengan data interval usia terbanyak adalah 1-5 tahun (50\%).

Didapatkan 3 bakteri penghasil ESBL. Kultur menggunakan spesimen kateter urin pasien yang dilakukan oleh Departemen Mikrobiologi Klinik RSUD Dr. Soetomo, Surabaya. Distribusi bakteri penghasil ESBL tertera pada Tabel 1.

Distribusi sensitivitas bakteri penghasil ESBL dari ketiga bakteri di atas hanya ditampilkan dua terbanyak, yaitu pada Klebsiella pneumoniae dan Escherichia coli. 
Tabel 1. Distribusi bakteri penghasil ESBL pada infeksi saluran kemih pasien anak

\begin{tabular}{lcc}
\hline Bakteri & $\begin{array}{c}\text { Frekuensi pasien } \\
\text { (orang) }\end{array}$ & $\begin{array}{c}\text { Persentase } \\
(\%)\end{array}$ \\
\hline Klebsiella pneumoniae & 34 & 60,7 \\
Escherichia coli & 21 & 37,5 \\
Klebsiella oxytoca & 1 & 1,8 \\
\hline Total & 56 & 100 \\
\hline
\end{tabular}

Distribusi uji sensitivitas bakteri penghasil ESBL tertera pada Tabel 2.

Terapi antibiotik definitif pasien dikelompokkan berdasarkan kesamaan struktur dan mekanisme kerja terhadap bakteri. Dari data rekam medik didapatkan antibiotik penicillin, ampicillin, dan cloxacillin dimasukkan dalam golongan penicillin. Golongan cephalosporin terdiri atas ceftriaxone dan cefotaxime. Golongan aminoglikoside terdiri dari gentamycin dan amikasin. Distribusi terapi definitif pasien tertera pada Tabel 3.

Pemilihan terapi antibiotik yang tepat sebagai pengobatan pasien infeksi ESBL diharapkan memiliki hasil luaran yang baik selama pasien dirawat. Status luaran pasien dengan kondisi klinis membaik, mulai sembuh, dan sembuh dimasukkan dalam kelompok membaik, sedangkan kondisi klinis memburuk, meninggal dimasukkan kelompok memburuk. Tabel 4 menyajikan data kesesuaian terapi dengan hasil luaran pasien infeksi ESBL setelah dirawat di rumah sakit.

Tabel 2. Distribusi uji sensitivitas bakteri penghasil ESBL terhadap antibiotik

\begin{tabular}{lcccc}
\hline \multirow{2}{*}{ Antibiotik } & \multicolumn{2}{c}{ Klebsiella pneumoniae $(\mathrm{n}=35)$} & \multicolumn{2}{c}{ Eschericia coli $(\mathrm{n}=21)$} \\
\cline { 2 - 5 } & Frekuensi & Persentase $(\%)$ & Frekuensi & Persentase(\%) \\
\hline Meropenem & 29 & 85,3 & 19 & 90,5 \\
Imipenem & 30 & 88,2 & 17 & 81,0 \\
Fosfomisin & 18 & 52,9 & 19 & 90,5 \\
Amikasin & 24 & 70,6 & 18 & 85,7 \\
Piperacillin tazobactam & 6 & 17,6 & 12 & 57,1 \\
Lefofloksasin & 19 & 55,9 & 11 & 52,4 \\
Gentamisin & 10 & 29,4 & 11 & 52,4 \\
Sefoperazone sulbactam & 9 & 26,5 & 8 & 38,1 \\
Siprofloksasin & 7 & 20,6 & 8 & 38,1 \\
Ampisilin sulbactam & 2 & 5,9 & 6 & 28,6 \\
Sefepim & 1 & 2,9 & 0 & 0 \\
\hline
\end{tabular}

Tabel 3. Distribusi terapi antibiotik definitif pada pasien anak ISK karena bakteri ESBL

\begin{tabular}{lcc}
\hline Golongan antibiotik definitif & frekuensi & persentase (\%) \\
\hline Meropenem & 14 & 25,00 \\
Sefalosporin & 12 & 21,43 \\
Aminoglikosid & 7 & 12,50 \\
Meropenem + Aminoglikosid & 5 & 8,93 \\
Penisilin & 5 & 8,93 \\
Penisilin + Aminoglikosid & 3 & 5,36 \\
Kloramfenikol & 2 & 3,57 \\
Penisilin + Kloramfenikol & 1 & 1,79 \\
Sefalosporin + Amoxiklaf & 1 & 1,79 \\
Amoxiclav + Meropenem + Aminoglikoside & 1 & 1,79 \\
Sefalosporin + Penisilin + Aminoglikosid & 1 & 1,79 \\
Tanpa antibiotik & 4 & 7,14 \\
\hline Total & 56 & 100 \\
\hline
\end{tabular}


Ahmad Siddiq Muhajir dkk: Gambaran terapi dan luaran pasien ISK oleh bakteri penghasil ESBL

Tabel 4. Distribusi luaran pasien berdasarkan kesesuaian terapi antibiotik definitif

\begin{tabular}{llcccc}
\hline kondisi membaik & & \multicolumn{3}{c}{ Hasil luaran pasien setelah dirawat } \\
\cline { 3 - 6 } & & $\begin{array}{c}\text { kondisi } \\
\text { memburuk }\end{array}$ & $\begin{array}{c}\text { tidak ada } \\
\text { keterangan }\end{array}$ & Total \\
& Sesuai & 20 & 6 & 1 & 27 \\
\cline { 2 - 6 } & & $(35,71 \%)$ & $(10,71 \%)$ & $(1,79 \%)$ & \\
\cline { 2 - 6 } $\begin{array}{l}\text { Kesesuaian terapi dengan } \\
\text { hasil uji sensitivitas } \\
\text { antibiotik }\end{array}$ & tidak sesuai & 22 & 3 & 1 & 26 \\
\cline { 2 - 6 } & tidak ada terapi & $(39,29 \%)$ & $(5,36 \%)$ & $(1,79 \%)$ & \\
\cline { 2 - 6 } & Total & $(3,57 \%)$ & 0 & 1 & 3 \\
& & 44 & 9 & 3 & 56 \\
\hline
\end{tabular}

\section{Pembahasan}

Uji sensitivitas antibiotik bakteri penghasil ESBL menunjukkan hasil bahwa golongan karbapenem (meropenem dan imipenem) dan amikacin memiliki sensitivitas paling tinggi pada Klebsiella pneumoniae. Pada Escherichia coli antibiotik golongan karbapenem, amikacin dan fosfomycin masih sangat sensitif. Penelitian uji pola sensitivitas antibiotik juga dilakukan pada bakteri penghasil ESBL di RSUD Dr. Soetomo Surabaya, RS Saiful Anwar Malang, dan RS Dr. Kariadi Semarang. Didapatkan data dari total 300 isolat bakteri penghasil ESBL yang berasal dari Klebsiella pneumoniae, Escherichia coli, dan Enterobacteriaceae memberikan hasil sensitivitas antibiotik amikacin, cefoperazonesulbactam, fosfomycin dan meropenem di atas $90 \%$. Meropenem menghasilkan daya sensitivitas paling besar dengan angka sensitivitas $100 \%$, sedangkan antibiotik cefotaxime dan ciprofloxacin memberikan hasil sensitivitas yang lemah. ${ }^{8} \mathrm{Uji}$ sensitivitas bakteri penghasil ESBL pada anak di serbia didapatkan data bahwa semua ESBL memiliki sensitivitas $100 \%$ terhadap antibiotik golongan karbapenem yang terdiri dari imipenem, meropenem, dan entarpenem.?

Clinical and Laboratory Standard Institute (CLSI 2011) merekomendasikan bahwa sefalosporin generasi ke-3 harus dihindari sebagai pilihan terapi ESBL meskipun memiliki hasil kultur yang sensitif. Berbagai studi terkait penelitian penggunaan antibiotik golongan sefalosporin generasi ke-3 seperti sefotaksim, sefoperazon memberikan hasil tanpa perbaikan klinis. Siproflosaksin walaupun bukan golongan sefalosporin, banyak studi ESBL menunjukkan angka resistensi yang tinggi. ${ }^{10} \mathrm{Hal}$ tersebut bisa disebabkan oleh dua kemungkinan, yaitu kecenderungan praktisi dokter yang menggunakan sefalosporin sebagai lini pertama terapi menggantikan sefalosporin, atau karena adanya transmisi gen resisten yang dikode bakteri pada saat pemakaian antibiotik kombinasi. ${ }^{11}$ European Committee on Antimicrobial Susceptibility Testing (EUCAST) menyatakan bahwa ESBL resisten terhadap semua antibiotik cephalosporin dan aztreonam. ${ }^{12}$ Kesimpulan yang sama dinyatakan CLSI (2010-2014) dan EUCAST (2009-2014) terkait hasil pola sensitivitas terhadap antibiotik betalaktam seperti sefotaksim, seftriakson, seftazidim, sefepime dan aztreonam yang memiliki resistensi tinggi terhadap ESBL. ${ }^{10,12} \mathrm{Hal}$ tersebut disebabkan oleh enzim Betalactamase yang dihasilkan oleh bakteri yang memiliki daya resistensi terhadap antibiotik golongan betalaktam karena mampu menghidrolisis betalactam ring pada antibiotik untuk tidak berikatan dengan transpeptidase pada dinding sel bakteri. ${ }^{6}$

Pasien infeksi bakteri penghasil enzim ESBL jika tidak diterapi dengan antibiotik sensitif sesuai kultur memungkinkan untuk menghasilkan outcome yang buruk setelah dirawat. Jika dilihat pada hasil uji sensitivitas pasien ini maka antibiotik golongan karbapenem, fosfomisin, dan amikasin yang masih memiliki nilai sensitivitas tinggi. Data klinis penggunaan karbapenem sebagai terapi pada wabah infeksi bakteri K.pneumoniae penghasil ESBL menunjukkan hasil yang memuaskan pada pasien yang diterapi dengan imipenem. $^{7}$

Karbapenem dianggap sebagai drug of choice untuk penyakit infeksi bakteri penghasil ESBL. ${ }^{6-7}$ Berdasarkan uji in-vitro didapatkan bahwa Karbapenem memiliki 
daya resistensi tinggi terhadap reaksi hidrolisis dari enzim betalaktamase bakteri. ${ }^{13}$ Karbapenem memiliki inti yang berbeda dibandingkan penisilin di mana terjadi pergantian methylene untuk sulfur dan ikatan ganda pada cincin. Terikat sangat kuat dengan afinitas tinggi pada PBP. Tidak mengalami hidrolisis oleh betalaktamase. ${ }^{6}$ Tidak ada bukti bahwa terapi kombinasi dengan betalactamase inhibitor dengan karbapenem dan antibiotik dari kelas lain lebih unggul untuk digunakan dari karbapenem saja. Sinergi beberapa kombinasi memang pernah ditemui, tetapi tidak pada semua golongan antibiotik. ${ }^{7}$ Analisis lebih lanjut pada ESBL dengan strain resisten terhadap karbapenem, ditemukan masih sensitif terdapat penggunaan fosfomisin dan amikasin sebagai alternatif terapi. Namun, sensitivitas yang rendah terhadap karbapenem mengindikasikan kemungkinan adanya resistensi yang tinggi sebagai perlawanan di kemudian hari. ${ }^{8}$

Kesesuaian terapi dengan hasil luaran membaik selama dirawat jika dibandingkan dengan terapi tidak sesuai kultur memiliki nilai yang tidak jauh berbeda. Laporan penelitian lain di India didapatkan data perbandingan keberhasilan terapi definitif menggunakan karbapenem. Dari total 396 pasien dengan hasil luaran membaik, 126 pasien berasal dari terapi karbapenem dan sisanya 270 menggunakan antibiotik bukan karbapenem dengan perbandingan treatment success rate $85,71 \%: 79,64 \% .{ }^{14}$ Laporan penelitian lain di Korea, pada pasien anak dengan kasus ISK oleh ESBL, tidak didapatkan perbandingan pemakaian terapi karbapenem maupun bukan. Keduanya menghasilkan angka treatment success rate yang sama-sama $100 \% .{ }^{15}$ Tidak ada pedoman khusus pada terapi pasien ISK oleh bakteri penghasil ESBL. Studi terkait perbandingan penggunaan terapi, terutama pada pasien anak masih sedikit. Namun, jika hasil luaran membaik dengan terapi bukan menggunakan karbapenem maka dapat disebabkan konsentrasi antimikroba yang dipertahankan tetap tinggi pada saluran eksresi urin. Meskipun nonkarbapenem diberikan untuk strain resisten, konsentrasi yang relatif tinggi dapat menyebabkan keberhasilan pengobatan walaupun bertentangan dengan hasil uji kepekaan antimikroba. ${ }^{15}$ Penggunaan antibiotik nonkarbapenem sebelum pasien kemudian beralih terapi karbapenem digolongkan dalam kelompok terapi karbapenem. Hal tersebut tidak bisa disimpulkan bahwa pemakaian karbapenem sesuai hasil uji sensitivitas tidak dipengaruhi antibiotik lain sebelumnya. Realitas praktik klinis menunjukkan pemakaian karbapenem identik pada pasien dengan kasus infeksi parah oleh bakteri ESBL dengan lenght of stay yang tinggi dikarenakan memang sensitivitasnya yang tinggi dan harganya yang mahal. Analisis lebih lanjut belum diketahui pengaruh karbapenem pada infeksi ringan yang disebabkan oleh bakteri ESBL. ${ }^{16}$

Keberhasilan penggunaan antibiotik pada kasus infeksi terdapat tiga aspek yang saling berkaitan, yaitu aspek antibiotik, kuman, dan pejamu. Dari aspek antibiotik sangat bergantung pada proses farmakokinetik dan farmakodinamik obat. Antibiotik diharapkan mampu mencapai lokasi infeksi dengan kadar yang cukup (melebihi kadar hambat minimal), penetrasi ke dalam sel bakteri dan bekerja mengganggu proses metabolisme bakteri sehingga bakteri tersebut menjadi tidak aktif atau mati, tetapi efek toksik pada sel pejamu diharapkan seminimal mungkin. Dari aspek pejamu, status keadaan klinis pasien sangat memengaruhi baik dari sistem imun, derajat infeksi, status gizi, genetik, dan penyakit komorbid lainnya. Sementara dari aspek kuman, jumlah konsentrasi dan daya sensitivitas kuman merupakan faktor utama keberhasilan terapi. ${ }^{17}$

\section{Kesimpulan}

Terapi antibiotik meropenem terbanyak pada pasien infeksi bakteri penghasil ESBL dengan sensitivitas terhadap antibiotik golongan karbapenem tinggi. Status luaran pasien dengan kondisi klinis membaik lebih banyak. Perbandingan hasil luaran pasien terhadap kesesuaian terapi tidak jauh berbeda.

\section{Ucapan terima kasih}

Penulis utama mengucapkan terima kasih kepada Priyo Budi Purnomo, dr., M.Si. selaku pembimbing pertama, Samsriyaningsih Handayani, dr.,M.Kes, M.Ed, Ph.D selaku pembimbing kedua, Dr. Florentina Sustini., dr., MS selaku penanggung jawab modul penelitian Fakultas Kedokteran Universitas Airlangga. Dekan Fakultas Kedokteran Universitas Airlangga Prof. Dr. Soetojo, dr., Sp.U (K), serta orang tua, keluarga, teman dan semua pihak yang tidak dapat penulis sebutkan satu per satu yang telah membantu proses penelitian ini. 
Ahmad Siddiq Muhajir dkk: Gambaran terapi dan luaran pasien ISK oleh bakteri penghasil ESBL

\section{Daftar pustaka}

1. Zorc JJ, Kiddoo DA, Shaw KN. Diagnosis and management of pediatric urinary tract infections. Clin Microbiol Rev 2005;18:417-22.

2. Knothe H, Shah P, Krcmery V, Antal M, Mitsuhashi S. Transferable resistance to cefotaxime, cefoxitin, cefamandole and cefuroxime in clinical isolates of Klebsiella pneumoniae and Serratia marcescens. Infection 1983;11:315-7.

3. Bauernfeind A, Hörl G. Novel R-factor borne betalactamase of Escherichia coli confering resistance to cephalosporins. Infection 1987;15:257-9.

4. World Healht Organization. Workshop on the containment of antimicrobial resistance in Europe. Wernigerode, Germany 26-27 February. WHO; 2004.

5. Sharma J, Meera S, Palap R. 2009. Detection of TEM and SHV in Escherichia Coli and Klabisella Pneumonia isolates in a tertiary care hospital from India. Indian J Med Res 2009;132:332-6.

6. Katzung, B. G. Farmakologi dasar dan klinik. Edisi ke10. Jakarta: EGC; 2002.

7. Paterson DL, Bonomo RA. Extended-Spectrum $\beta$-lactamases: A clinical update. Clin Microbiol Rev 2005;18:657-86.

8. Kuntaman, Santoso S, Wahjono H, Mertiniangsih NM, Lestari ES, Farida H, dkk. The sensitivity pattern of extended spectrum beta-lactamases producing bacteria against six antibiotic that routinely used in clinical setting. J Indon Med Assoc 2011;61:482-6.

9. Deana M, Gusman V, Mihajlović-ukropina $M$, Jelesić Z, Milosavljević B. Bloodstream infections in children caused by extended spectrum beta-lactamaseproducing Klebsiella pneumoniae. Arch Biol Sci Belgrade 2012;64:1339-47.

10. CLSI. Performance standards for antimicrobial susceptibility testing; eighteenth informational supplement. M100-S18, Vol.28 No.1, Replaces M-100-S17, Vol.27 No.1. [serial online]; 2011. Diakses 14 Januari 2016. Didapat dari: www. CLSI.org

11. Paterson DL, Mulazimoglu L, Casellas JM, Ko WC, Goossens H, Von Gottberg A, dkk. Epidemiology of ciprofloxacin resistance and its relationship to extendedspectrum beta-lactamase production in Klebsiella pneumoniae isolates causing bacteremia. Clin Infect Dis 2000;30:473-8.

12. European Committee on Antimicrobial Susceptibility Testing (EUCAST). Update of ESBL interpretation. European society of clinical microbiology and infectious disease. Diakses 14 Januari 2016. Didapat dari: www. eucast.org.

13. Rupp, Mark, Paul. Extended spectrum $\beta$-lactamase (ESBL)-producing Enterobacteriaceae considerations for diagnosis, prevention and drug treatment. USA: Department of Internal Medicine, University of Nebraska Medical Center. Drugs 2003; 63:353-65.

14. Trivedi M, Patel V, Soman R, Rodriguez C, Singhal T. The outcome of treating ESBL infections with carbapenems vs. non carbapenem antimicrobials. Assoc Physic India J 2012;60:28-30.

15. Lee B, Kang SY, Kang H, Yang N, Kang HG, Cheong $\mathrm{H}$, dkk. Outcome of Antimicrobial therapy of pediatric urinary tract infections caused by extended-spectrum $\beta$-lactamase-producing Enterobacteriaceae. Korean Soc Infect Dis 2013;45:415-21.

16. Paterson DL, Mulazimoglu L, Casellas JM, Ko WC, Goossens H, Von Gottberg A, dkk. Epidemiology of ciprofloxacin resistance and its relationship to extendedspectrum beta-lactamase production in Klebsiella pneumoniae isolates causing bacteremia.Clin Infect Dis 2000;30:473-8 .

17. Lukman ZA, Pemilihan antibiotik yang rasional. Medical Review 2014;27:40-5. 